\title{
CALL FOR PAPER:
}

Redaksi menerima naskah hasil penelitian, kajian maupun pemikiran kritis mengenai isu-isu dalam lingkup bidang administrasi publik/Negara yang orisinil dan belum pernah dimuat di jurnal atau majalah lain. Naskah diketik dalam Ms Word menggunakan Bahasa Indonesia atau Bahasa Inggris sepanjang 15-20 halaman, ukuran A4, huruf Times New Roman 12pt, dan spasi tunggal. Naskah disubmit online melalui http://www.samarinda.lan.go.id/jba. serta dilengkapi dengan Persyaratan Keaslian Naskah dan Daftar Riwayat Hidup Penulis. Redaksi berhak melakukan penilaian dan penyuntingan terhadap naskah yang masuk. Naskah yang lolos seleksi oleh Redaksi, akan direview oleh Mitra Bestari (Reviewers). Petunjuk penulisan selengkapnya dapat dilihat di bagian belakang Jurnal Borneo Administrator atau di http://www.samarinda.lan.go.id/jba

Sub tema naskah meliputi:

- Kebijakan Publik

- Manajemen Publik

- Inovasi Pemerintah

- Pelayanan Publik

- Isu-isu lain dalam lingkup bidang administrasi publik

\section{JBA SUDAH TERINDEKS DI :}




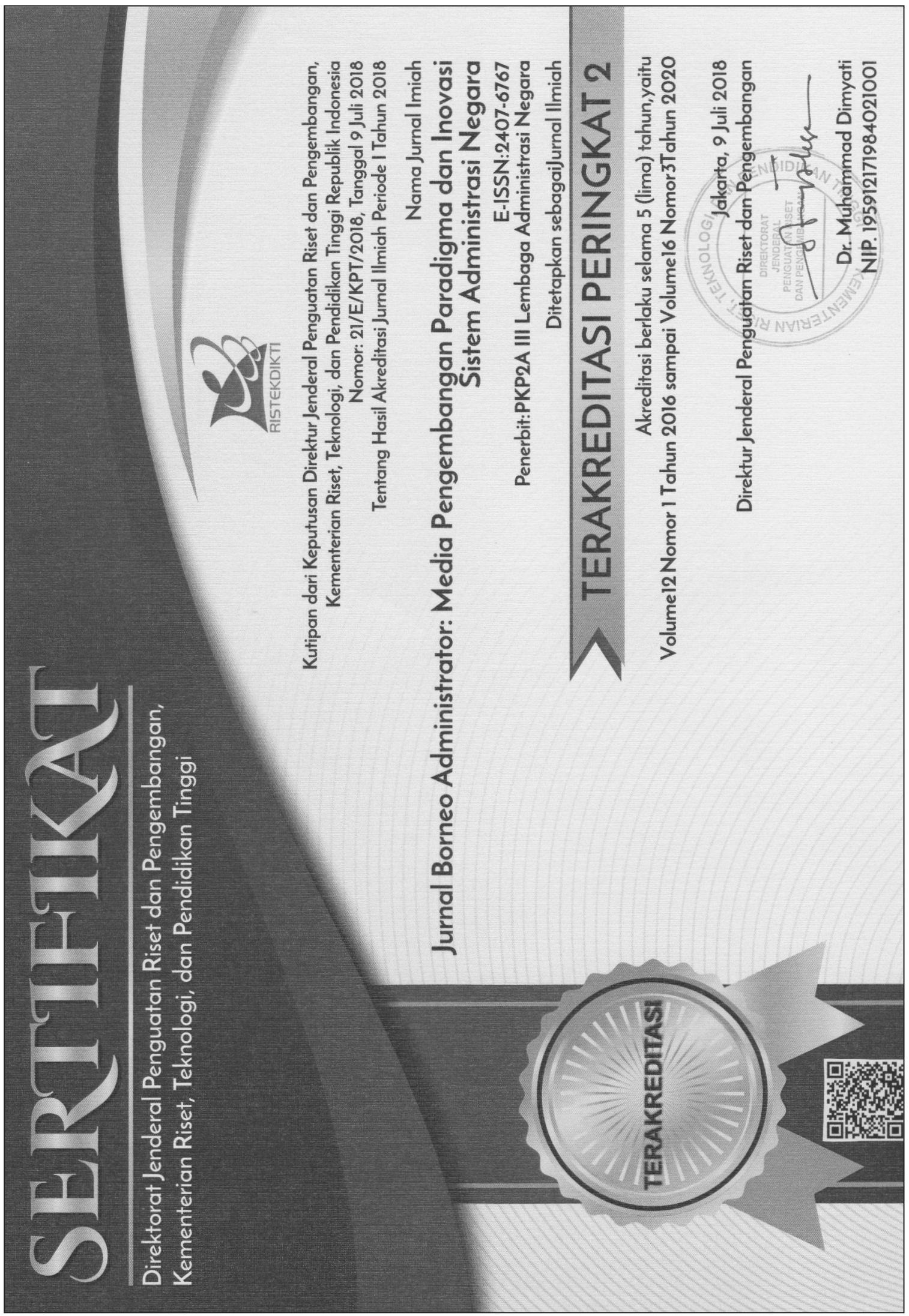


Jurnal Borneo Administrator diterbitkan 3 kali setahun setiap bulan April, Agustus, dan Desember oleh Pusat Pelatihan dan Pengembangan dan Kajian Desentralisasi dan Otonomi Daerah Lembaga Administrasi Negara.

\section{Pengarah:}

Kepala Puslatbang KDOD LAN

Pemimpin Redaksi/Penanggung Jawab (Editor in Chief): Dr. Mariman Darto, M.Si. (Manajemen SDM)

Redaktur (Journal Editor):

Siti Zakiyah, S.Si, M.S.E, MA (Ekonomi, Pelayanan Publik)

Rustan A, SP., MA, M.S.E (Birokrasi dan Manajemen Pelayanan Publik)

Kemal Hidayah, SH (Hukum, Administrasi Publik)

Penyunting (Section Editor):

Fani Heru Wismono, S.E., M.A. (Administrasi Publik)

Mayahayati Kusumaningrum, S.E., M.Ec.Dev. (Birokrasi dan Manajemen Pelayanan Publik)

Maria A.P Sari, S.Sos., MA., MAP (Administrasi Publik)

Dr. Ayuning Budiati, S.IP., MPMM (Kebijakan Publik)

Dra. Tri Yuniningsih, M.Si (Kebijakan Publik)

Copy Editor \& Lay Out Editor:

Wildan Lutfi A., S.E. (Administrasi Publik)

Arbain, S.Pd., M.Pd. (Bahasa Inggris)

Puji Retno Hardiningtyas, S.S., M.Hum (Bahasa Indonesia)

Mitra Bestari (Reviewers):

Dr. Samodra Wibawa, M.Sc.Mag.rer.publ. (Administrasi Publik, Universitas Gadjah Mada, Yogyakarta)

Dr. Bevaola Kusumasari (Manajemen Publik, Universitas Gadjah Mada, Yogyakarta)

Wawan Sobari, S.IP., MA., Ph.D (Politik dan Kebijakan Publik, Universitas Brawijaya, Malang)

Yogi Suwarno, S.IP., MA., Ph.D (Administrasi Publik, STIA-Lembaga Administrasi Negara, Jakarta)

Fadillah Putra, MPAff, Ph.D (Perencanaan Pembangunan, Universitas Brawijaya, Malang)

Suwatin Miharti, Ph.D (Administrasi Negara, Lembaga Administrasi Negara RI, Jakarta)

Dr. Sujarwoto, S.IP., M.Si., MPA (Administrasi Publik, Universitas Brawijaya, Malang)

Dr. Dwiyanto Indiahono, S.Sos., M.Si (Kebijakan Publik, Universitas Jenderal Soedirman, Purwokerto)

Dr. Tedi Sudrajat, SH., MH (Hukum Birokrasi, Universitas Jenderal Soedirman, Purwokerto)

Prof. Muradi, SS., M.Si., M.Sc., Ph.D (Politik dan Tata Pemerintahan, Universitas Padjadjaran, Bandung)

Dr. Rachma Fitriati, M.Si., M.Si (Han) (Kebijakan Publik, Universitas Indonesia, Jakarta)

Prof. Dr. Hj. Eny Rochaidah, M.Si (Ekonomi, Universitas Mulawarman, Samarinda)

Dr. Maskun, SH., LL.M (Hukum, Universitas Hasanuddin, Makassar)

Dr. Nurhadi Susanto, SH, M.Hum (Hukum Administrasi Negara, Universitas Gadjah Mada)

Istiqomah, SE., M.Sc., Ph.D (Ekonomi dan Bisnis, Universitas Jenderal Soedirman, Purwokerto)

Yogi Suprayogi Sugandi, S.Sos., MA., Ph.D (Kebijakan Publik, Universitas Padjadjaran, Bandung)

Ida Widianingsih, S.IP., MA., Ph.D (Administrasi Publik, Universitas Padjadjaran, Bandung)

Prof. Jaka Sriyana, Ph.D (Ekonomi Regional, Universitas Islam Indonesia, Yogyakarta)

Ely Susanto, S.IP., MBA., Ph.D (Administrasi Publik, Universitas Gadjah Mada, Yogyakarta)

Redaksi Pelaksana:

Lia Rosliana, S.Psi ; Novi Prawitasari, S.Sos

\section{Desain Grafis:}

Ricky Noor Permadi, S.Sos

\section{Alamat:}

Pusat Pelatihan dan Pengembangan dan Kajian Desentralisasi dan Otonomi Daerah Lembaga Administrasi Negara (Puslatbang KDOD LAN)

Jl. H.M. Ardans II, SH. (Ring Road III) Samarinda 75124

Email: borneo.jurnal@gmail.com

URL : http://www.samarinda.lan.go.id/jba 


\section{Daftar Isi}

\section{Analisa}

KONTEKSTUALISASI ADOPSI KEBIJAKAN: STUDI KASUS

$117-136$

KEBIJAKAN PENGENDALIAN COVID-19 DI KOREA SELATAN

Fajar Iswahyudi, Muhadjir Darwin, Heruanto Adna, dan Pande

Made Kutanegara

UPAYA PENINGKATAN KAPABILITAS APARAT PENGAWASAN

$137-158$

INTERN PEMERINTAH (APIP) DI ACEH MELALUI INTERNAL

AUDIT CAPABILITY MODEL (IACM)

Rati Sumanti

IMPLEMENTASI KEBIJAKAN PENGEMBANGAN KAWASAN

$159-178$

EKONOMI KHUSUS TANJUNG KELAYANG

Alvin Rizalsan dan Vishnu Juwono

EQUAL EMPLOYMENT OPPORTUNITY IN INDONESIA: ANTECEDENT

$179-198$

OF HUMAN RESOURCE MANAGEMENT PRACTICES AND SERVICE

PERFORMANCE OF GOVERNMENT EMPLOYEES IN TANJUNGPINANG

Wayu Eko Yudiatmaja

PEMETAAN RISET REFORMASI BIROKRASI DI INDONESIA

Fikri Habibi

PENGARUH KEMAMPUAN MENYUSUN PERENCANAAN DAN

MEMOBILISASI STAKEHOLDER TERHADAP PENCAPAIAN

TARGET KINERJA PEJABAT PUBLIK DI INDONESIA

Putri Wulandari Atur Rejeki dan Yuyu Yuningsih

ANALISIS KEBIJAKAN PENANGANAN WABAH COVID-19:

PENGALAMAN INDONESIA

$199-230$

Leo Agustino

Petanjuk Penulisan 


\section{Salam Redaksi}

Syukur Alhamdulillah, Jurnal Borneo Administrator Volume 16 Nomor 2 Tahun 2020 dapat terbit sesuai jadwal yang ditentukan. Sebagai informasi terbaru, mulai nomor ini, Redaksi Jurnal Borneo Administrator menambah jumlah naskah yang diterbitkan, dari enam naskah artikel menjadi tujuh naskah artikel. Jurnal Borneo Administrator juga tengah mengajukan reakreditasi melalui aplikasi ARJUNA dikarenakan masa berlaku akreditasi akan berakhir pada akhir tahun ini. Semoga Jurnal Borneo Administrator kembali mempertahankan statusnya sebagai Jurnal Terakreditas Nasional Sinta 2.

Di tengah pandemi Covid-19 yang masih mengkhawatirkan, kami sebagai pengelola Jurnal Borneo Administrator juga masih menjalani sistem kerja dari rumah. Sebuah adaptasi kebiasaan baru yang akan dijalankan oleh hampir sebagian besar dunia kerja saat ini. Meski demikian, kondisi ini tidak menyurutkan semangat kami dalam mengelola Jurnal Borneo Administrator. Tidak ketinggalan, JBA pun memuat beberapa artikel yang secara khusus membahas COVID-19.

Terbitan Volume 16, Nomor 2, Agustus Tahun 2020 kali ini memuat tujuh artikel berbobot dengan tema dan ulasan menarik yang dikontribusikan oleh para penulis dari berbagai instansi di Indonesia. Artikel pertama ditulis oleh Fajar Iswahyudi, Muhadjir Darwin, Agus Heruanto Hadna, dan Pande Made Kutanegara yang secara runtun mengulas Kontekstualisasi Adopsi Kebijakan: Studi Kasus Kebijakan Pengendalian Covid-19 di Korea Selatan. Kemudian artikel kedua ditulis oleh Rati Sumanti, dengan judul Upaya Peningkatan Kapabilitas Aparat Pengawasan Intern Pemerintah (APIP) di Aceh Melalui Internal Audit Capability Model (IACM). Artikel ketiga ditulis oleh Alvin Rizalsan Chaniago dan Vishnu Juwono dengan topik Implementasi Kebijakan Pengembangan Kawasan Ekonomi Khusus Tanjung Kelayang.

Selanjutnya Wayu Eko Yudiatmaja mengurai tentang Kesempatan Kerja yang Setara di Indonesia: Anteseden dari Praktik Manajemen Sumber Daya Manusia dan Kinerja Pelayanan Pegawai di Kota Tanjungpinang secara jelas pada artikel keempat. Sedangkan artikel yang kelima ditulis oleh Fikri Habibi dengan judul Pemetaan Riset Reformasi Birokrasi di Indonesia. Kemudian artikel keenam yang berjudul Pengaruh Kemampuan Menyusun Perencanaan dan Memobilisasi Stakeholder Terhadap Pencapaian Target Kinerja Pejabat Publik di Indonesia, ditulis oleh Putri Wulandari Atur Rejeki dan Yuyu Yuningsih. Sebagai yang terakhir adalah artikel yang ditulis oleh Leo Agustino dengan topik pembahasan Analisis Kebijakan Penanganan Wabah Covid-19: Pengalaman Indonesia.

Akhirnya, JBA mengucapkan terima kasih dan penghargaan yang tinggi kepada tim pengelola JBA Tahun 2020 serta kepada para mitra bestari (reviewers). JBA tidak akan pernah berhenti untuk mengedepankan kualitas artikel yang diterbitkan dan terus berusaha secara konsisten untuk mempersiapkan dan mempersembahkan pengetahuan baru dalam lingkup administrasi publik. Semoga apa yang JBA upayakan ini selalu memberikan inspirasi dan ruang kemanfaatan yang semakin besar bagi kemajuan bangsa dan Negara Indonesia.

Selamat Membaca.

Stay safe, stay healthy, and stay at home 